\title{
On-farm phenotypic characterization of Mursi cattle in its production environment in South Omo Zone, Southwest Ethiopia
}

\author{
Endashaw Terefe ${ }^{1}$, Tadelle Dessie ${ }^{2}$, Aynalem Haile ${ }^{3}$, Wudyalew Mulatu ${ }^{2}$ and Okeyo Mwai ${ }^{4}$ \\ ${ }^{1}$ Arsi University, College of Agriculture and Environmental Science, P.O. Box 193, Asella, Ethiopia; ${ }^{2}$ International Livestock Research \\ Institute (ILRI), P.O. Box 5689, Addis Ababa, Ethiopia; ${ }^{3}$ International Center for Agricultural Research in the Dry Areas (ICARDA), \\ P.O. Box 5689, Addis Ababa, Ethiopia; ${ }^{4}$ International Livestock Research Institute (ILRI), P.O. Box 30709, Nairobi, Kenya
}

\begin{abstract}
Summary
This study was conducted to characterize the morphological peculiarities and performance characteristics of Mursi cattle in its production environment managed by Bodi and Mursi pastoral communities in Southern Ethiopia. A structured questionnaire survey, group discussion, cattle morphological measurements and morphological descriptions were used to collect data. One hundred and two household heads were selected to administer the questionnaire and 201 adult cattle were selected for morphological description and body measurements. The Mursi cattle population was found to have variable coat colour type (85.9 percent) and coat colour pattern (51.3 percent). Body length, chest girth, withers height, rump width and rump length of Mursi cattle were 122.1 $\pm 0.9,144.5 \pm 0.9$, $113 \pm 0.1 .1,36.9 \pm 0.3$ and $20.4 \pm 0.3 \mathrm{~cm}$, respectively. Morphological measurements of most linear traits show no difference in the two locations but all measurements vary $(P<0.001)$ between males and females. Estimated age at first calving was 4.6 years and was significantly $(P<0.0001)$ higher in the Mursi area, while the calving interval $(14.5$ months $)$ and cow reproductive life $(14.2$ years) were the same in both locations. Average daily milk yield (2.1 litres) and lactation length (7.8 months) of Mursi cattle in the two locations were similar. Cattle production was constrained by high disease prevalence, seasonal feed availability, and water shortage, with frequent drought. Trypanosomosis, black leg, anthrax and skin diseases are major cattle diseases reported in the two study areas. Because of its peculiar morphological characteristics, including large body frame, higher production performance, and survivability in the harsh environment, the Mursi cattle can be used as an alternative genetic resource for production improvement programs.
\end{abstract}

Keywords: body measurement, breed characterization, Mursi cattle, morphological description

\begin{abstract}
Résumé
Cette étude a été menée dans le but de caractériser les particularités morphologiques et les performances productives des bovins Mursi dans son milieu de production, géré par les communautés pastorales Bodi et Mursi dans le Sud de l'Éthiopie. Un questionnaire structuré, un groupe de discussion et des mesures et des descriptions morphologiques des bovins ont été utilisés pour la collecte des données. Cent-deux chefs de famille ont été sélectionnés pour le questionnaire alors que 201 animaux adultes ont été choisis pour la description morphologique et les mesures corporelles. Il a été observé que la population bovine Mursi présente des couleurs ( 85,9 pour cent) et des motifs de la robe $(51,3$ pour cent) variés. La longueur du corps, le périmètre thoracique, la hauteur au garrot et la largeur et la longueur de la croupe chez les bovins Mursi ont été de 122,1 $\pm 0,9,144,5 \pm 0,9,113 \pm 0,1,36,9 \pm 0,3 \mathrm{et} 20,4 \pm 0,3 \mathrm{~cm}$, respectivement. Aucune différence n'a été décelée entre les deux zones pour ce qui est de la plupart des mesures linéaires mais toutes les mesures ont varié $(P<0.001)$ entre mâles et femelles. L'âge estimé à la première mise bas a été de 4,6 ans et a été significativement $(P<0.0001)$ plus élevé dans le territoire Mursi, alors que l'intervalle entre mises bas $(14,5$ mois $)$ et la vie reproductive des vaches $(14,2$ ans) ont été les mêmes dans les deux zones. La production moyenne journalière de lait (2,1 litres) et la durée de la lactation (7,8 mois) ont été similaires pour les bovins Mursi des deux territoires. La production du bétail a été limitée par une prévalence élevée de maladies, par la variation saisonnière dans la disponibilité en aliments et par le manque d'eau, dû aux fréquentes sécheresses. La trypanosomiase, le charbon symptomatique, la fièvre charbonneuse et les maladies cutanées ont été les principales maladies identifiées chez les bovins des deux zones étudiées. En raison de leurs caractéristiques morphologiques particulières, parmi lesquelles leur grand format corporel, leurs plus grandes performances productives et leur capacité de survie en milieu hostile, les bovins Mursi peuvent être utilisés comme une ressource génétique alternative dans les programmes d'amélioration de la production.
\end{abstract}

Mots-clés: bovins Mursi, description morphologique, mesure corporelle, caractérisation raciale

\section{Resumen}

Este estudio fue llevado a cabo con el fin de caracterizar las peculiaridades morfológicas y los rendimientos productivos del ganado bovino Mursi en su ambiente de producción, gestionado por las comunidades pastoriles Bodi y Mursi en el Sur de Etiopía. Para la toma de los datos, se emplearon un cuestionario estructurado, un grupo de debate y medidas y descripciones morfológicas del ganado. Ciento 
dos cabezas de familia fueron escogidos para el cuestionario mientras que se seleccionaron 201 animales adultos para la descripción morfológica y las medidas corporales. Se observó que la población bovina Mursi presenta colores (85,9 por ciento) y patrones de color de la capa (51,3 por ciento) variables. La longitud corporal, la circunferencia torácica, la altura a la cruz y la anchura y la longitud de la grupa en el ganado bovino Mursi fueron, respectivamente, de 122,1 $\pm 0,9,144,5 \pm 0,9,113 \pm 0,1,36,9 \pm 0,3$ y $20,4 \pm 0,3 \mathrm{~cm}$. No se detectaron diferencias entre las dos ubicaciones para la mayoría de los parámetros lineales, si bien todas las medidas variaron $(P<0.001)$ entre machos y hembras. La edad al primer parto estimada fue de 4,6 años y fue significativamente $(P<0.0001)$ mayor en el área Mursi, mientras que el intervalo entre partos (14,5 meses) y la vida reproductiva de las vacas (14,2 años) fueron iguales en ambas localizaciones. La producción media diaria de leche (2,1 litros) y la duración de la lactación (7,8 meses) fueron similares entre las dos áreas para el ganado Mursi. La producción del ganado se vio limitada por la alta prevalencia de enfermedades, por la variabilidad estacional en la disponibilidad de alimento y por la escasez de agua, debida a las frecuentes sequías. La tripanosomiasis, el carbunco sintomático, el ántrax y las enfermedades cutáneas fueron las principales enfermedades identificadas en el ganado bovino en las dos áreas de estudio. Debido a sus peculiares características morfológicas, entre las cuales se incluye su gran formato corporal, su mayor rendimiento productivo y su capacidad para sobrevivir en un ambiente hostil, el ganado bovino Mursi puede ser utilizado como un recurso genético alternativo en los programas para la mejora de la producción.

Palabras clave: ganado bovino Mursi, descripción morfológica, medida corporal, caracterización racial

Submitted 15 September 2014; accepted 14 April 2015

\section{Introduction}

Ethiopia is home to diverse cattle genetic resources that are adapted to and distributed in different agro-ecological zones of the country. As a result, cattle production is one of the main components of agricultural activities in all parts of the country. For smallholder farmers and pastoralists, cattle play multiple roles as source of food, income and serve as an asset and security against risks (Terefe et al., 2012). The multi-function of cattle genetic resources in the country is identified through production system and breed characterization studies in their natural production environment (FAO, 2012).

So far, several cattle breed studies have been conducted in Ethiopia to identify the available cattle genetic resources, and describe their phenotypic and genetic diversity, husbandry practices, production systems and breed performances (Albero and Haile Mariam, 1982a, 1982b; Rege, 1999; Rege and Tawah, 1999; Ayalew et al., 2004). These early breed identification and characterization studies in the country classified the available cattle genetic resources into five major groups viz, Large East African Zebu, Small East African Zebu, Senga, Zenga and the Taurine (humpless shorthorn) breeds (Rege, 1999; Rege and Tawah, 1999). These major breed groups were further classified into more than 32 breeds/ecotypes (DAGRIS, 2007). Furthermore, molecular characterization has shown high genetic diversity between and within breeds/ populations (Zerabruk et al., 2012).

The Mursi cattle breed is classified as Small East African Zebu in the Abyssinian Shorthorn subgroup (Rege and Tawah, 1999). This breed group is believed to have descended from zebu cattle that were introduced into Africa (FAO, 2007). The Mursi cattle breed has a relatively large body size compared with other breeds of the subgroup (Rege and Tawah, 1999). The large body size is due to some ancestral linkage with the Large East
African Zebu subgroup. The ancestral linkage might be due to geographical proximity of the breed distribution, human migration, long-distance pastoralist travel in search of pasture and water for their cattle, and markets (Fedlu et al., 2007).

The Mursi and Bodi pastoral communities keep the Mursi cattle in the Southwestern rangelands, South Omo zone (Rege, 1999). The pastoralists prefer the breed due to its perceived relative trypanotolerance (that is, its ability to survive and produce under trypanosomosis challenge) in trypanosomosis epidemic areas (Terefe et al., 2015), where there is little veterinary services. The study reported here is part of a project, which designed to study phenotypic characterization and trypanosomosis prevalence in Mursi cattle breed in its production environment. Therefore, this paper reports the morphological characteristics, production and reproduction performance, and identifies the major production constraints of Mursi cattle in Southwestern Ethiopia.

\section{Materials and method}

\section{Study area}

The study was conducted in Southern Nations Nationalities and Peoples Regional State, South Omo Administrative Zone in Salamago Wereda, Southwest Ethiopia. It is $870 \mathrm{~km}$ to the southwest of Addis Ababa and located in between $6^{\circ} 19^{\prime}$ and $7^{\circ} 10^{\prime} \mathrm{N}$ latitude, and $15^{\circ} 12^{\prime}$ and $22^{\circ}$ $25^{\prime} \mathrm{E}$ longitude with total land area of 451.12 square $\mathrm{km}$. The Wereda has two major agro-climatic zones; the midland that covers 33 percent of the total land and the rest 67 percent of the area is low land. The mean annual temperature was recorded to be $29{ }^{\circ} \mathrm{C}$ (ranges from 20 to 37.5 ${ }^{\circ} \mathrm{C}$ ). The average altitude of the Wereda is $971 \mathrm{~m}$ and receives bimodal rainfall, in which the long rainy season 
is in the months of March to June, while the short rainy season occurs in the months of August to October. Scattered woodland, savanna grass and large grassland plains dominate the vegetation type of the study area. Acacia, Combretum and Grewia are common woody plant species, whereas Cynodon, Brachiaria, Heteropogon, Cymbopogon, Aristida and Chlorisare common herbaceous grass species found in the study area (Tesfaye, 2008). Two locations, Mursi and Bodi areas, where the Mursi and Bodi pastoral communities live, respectively, were selected for this study. The two pastoral communities keep the Mursi cattle breed and share common territorial boundary and the locations also characterized by tsetse fly infested area, where trypanosome is prevalent (Terefe et al., 2015).

\section{Sampling and data collection}

Two hundred and one animals (28 males and 173 females) were selected from the Bodi and Mursi pastoral communities' household herd for morphological description and body measurements. The morphological characteristics such as coat colour pattern, coat colour type, horn type, horn orientation, horn shape, hump size, hump orientation, hump position and temperament were recorded according to FAO cattle morphological characteristics descriptor manual (FAO, 2012) and Ayalew and Rowlands (2004). Basic temperament of an animal was described in docile, moderately tractable and aggressive during handling for body measuring and blood sampling. Body measurements (body length, chest girth, height at wither, rump length, rump width, tail length and other traits) were made on adult animals using graduated measuring tape to $0.5 \mathrm{~cm}$ precision. One hundred and two heads of household (43 from Bodi and 59 from Mursi pastoral communities) were selected for questionnaire survey. Structured questionnaires were designed to collect data communities' responses on cattle performance, feed resource and utilization, major cattle production constraints and disease challenges that impede cattle production in the area. Additional information such as cattle management, major cattle production constraints and information how the community cope seasonal problems were collected through group discussion with community elders.

\section{Data analysis}

Data on physical body measurements were analysed using general linear model procedure of SAS $\left(\mathrm{SAS}^{\circledR}\right.$, Cary, North Carolina) in which sex of cattle and locations were fitted as explanatory fixed effects while body length, chest girth, withers height and other measured traits were response variables. Descriptive statistics was employed to analyse data on reproductive performance (age at first mating, age at first calving, calving interval and reproductive lifespan) and productive performance (daily milk yield and lactation length). Independent sample $t$-test was employed to compare the significance level of the two locations. Frequency statistics were used to analyse body morphology such as coat colour type and coat colour pattern, horn shape and orientation, hump size and orientation, udder size and animal temperament.

The morphological variability, that is, variability in coat colour, coat colour pattern, hump size, hump orientation, horn nature, horn orientation and shape, and temperament of individuals in the population was analysed using the coefficient of unalikablity. This measures the withinpopulation variability of categorical variables on a scale from 0 to 1 . The higher the value, the more unalike the qualitative variables are. The coefficient of unalikablity $\left(u_{2}\right)$ is calculated using the following formula and is equal to one minus the sum of square of the proportion $\left(P_{i}\right)$ of each category response (Kader and Perry, 2007).

$$
\boldsymbol{u}_{2}=1-\sum_{i} p_{i}^{2}
$$

Rank indices of major cattle production constraints were calculated as the sum of weighted number of response for criterion ( $n$ times number of response criterion ranked $1 \mathrm{st}+n-1$ times number of response ranked $2 \mathrm{nd}+\cdots+1$ times number of response ranked $n$ th) given to a criteria divided by the total sum of responses under each rank ( $n$ times total response ranked $1 \mathrm{st}+n-1$ times total response ranked $2 \mathrm{nd}+\cdots+1$ times total response ranked $n$ th) for overall criteria; where $n$ is the number constraints to be ranked.

\section{Result and discussion}

\section{Morphological characteristics of Mursi cattle \\ Qualitative body description}

Qualitative body description of Mursi cattle population show variable coat colour pattern and colour types among individual cattle (Figure 1). The most commonly observed coat colour patterns were plain (64.1 percent), pied (25.6 percent) and spotted (10.3 percent) with different colour combinations and were similar in the two study locations. Males predominantly have plain coat colour (68 percent) and while the rest 32 percent possess pied coat colour. Similarly most (63.5 percent) of the female cattle population were of plain coat colour, while 24.7 percent were pied and 11.8 percent of spotted coat colour patterns.

The dominant plain coat colours of Mursi cattle breed were 22.6 percent red, 18.5 percent white and 11.3 percent black, while the rest 14.4 percent were different colour types such as grey, brown and fawn. The pied coat colour are variable, in which white is found to be dominant colour that covers most part of animals' body with red, black or brown combination (14.3 percent). Black dominated black-white or black-red pied coat colour comprises 8.2 percent in proportion. A dominant red colour with white combination made up the lowest proportion (8.2 percent) of the total population. The remaining 2.5 percent of the population consists of different coat colour 


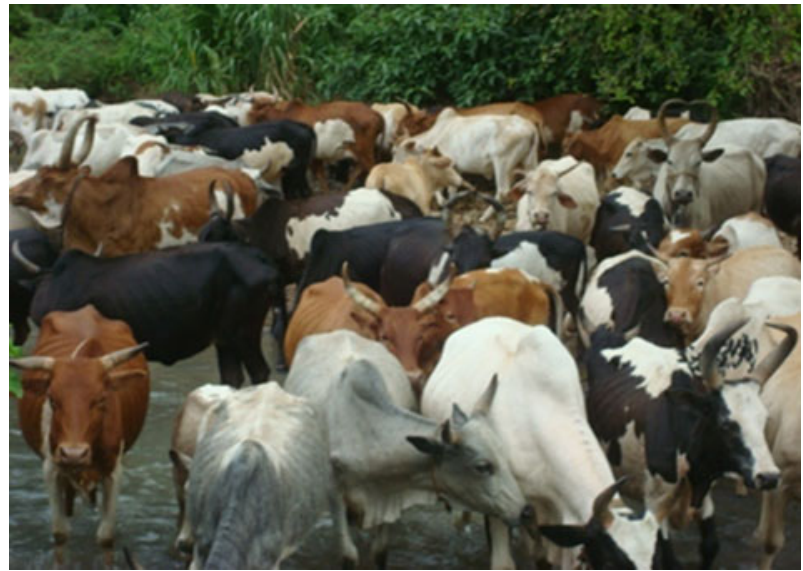

Figure 1. Variable coat colour types and colour patterns of a Mursi cattle herd.

combinations (Table 1). Rege and Tawah (1999) also reported high coat colour variability for the breed. The variable coat colour probably helps the breed to adapt the very hostile environment through avoiding effects of radiation and heat stress (Olson et al., 2003) and some colours do not attract the tsetse fly, preventing it landing, and this averts the fly biting the animal (Makokha et al., 2006).

Particular morphological characteristics of Mursi cattle breed include its shiny and smooth hair type with large curved horns (Figures 1-3). Of the total population, 69.4 percent possess straight horns and some, (22.8 percent) possess forward oriented horns. The common horn shape is curved (82.4 percent), while some possess straight upward (15.0 percent) and most of the cattle (57.7 percent) have artificially modified horns. Artificial horn modification is manipulation of cattle horn from an early age to give the horn special shape desired by the owners. Horn modification is usually done through fastening the horn with a knotted rope to give a curved and twisted shape. The tips of the two horns come close together and form circular shape through time (Figures $3 \mathrm{~A} \& \mathrm{~B}$ ). The purposes of horn modification are to give the animal a special look, ease identification of ownership and to protect the cattle from harming each other or humans. It also provides ease of restraint during milking, blood collection, or medication.

The cattle breed is also characterized by its thoracic hump, which is distinctive characteristic feature of zebu cattle. Most (97.4 percent) of the cattle in the population possess an erect hump, while 2.6 percent have a laterally drooped hump. The hump size of the cattle was variable; most of the animals, (64.2 percent), possess a small hump, whereas the rest (22.3 and 13.5 percent) have medium and large humps, respectively. The male cattle have large (48 percent) and medium (44 percent) humps, whereas, the highest proportion of female cattle (72.6 percent) possess a small hump. As in other indigenous zebu cattle, the udder size of most cows (63.3 percent) is small, whereas, a few cows ( 32.0 percent) possess medium udder size and only 4.7 percent have a large udder size. Concerning the temperament of Mursi cattle, 75.5 percent of the animals were found to be very docile, while 19.4 percent were moderate and the rest 5.1 percent were very aggressive (Table 2). Male cattle were observed more aggressive than females. The pastoral communities in the two locations used cattle as a source of milk and blood for consumption (Terefe et al., 2012), and as a result, animals with good temperament are preferable for easy handling or restraining during milking, blood collection and medication. Therefore, docile cattle remain in the herd through long-term selection for docility.

The morphological unalikability analysis indicated that the cattle breed is very variable. From these morphological traits, 85.9 percent of the population was unlikeable in coat colour type, while, 51.3 percent of the population differs in coat colour pattern. Similarly, the variability of individuals due to hump and udder size was variable with unalikablity coefficient of 0.52 and 0.49 , respectively. Lower unalikablity coefficient was observed for hump orientation (0.05) and temperament $(0.39)$ of the population. The variability of the cattle breed due to horn nature $(0.49)$, orientation $(0.46)$

Table 1. Colour pattern and colour type (\%) of Mursi cattle in the Bodi and Mursi pastoral areas of South Omo zone, Southwest Ethiopia.

\begin{tabular}{|c|c|c|c|c|c|c|}
\hline \multicolumn{2}{|c|}{ Colour pattern and type } & \multirow[t]{2}{*}{ Overall } & \multicolumn{2}{|c|}{ Location } & \multicolumn{2}{|c|}{ Animal sex } \\
\hline & & & Bodi & Mursi & Male & Female \\
\hline \multirow[t]{3}{*}{ Coat colour pattern } & Plain & 64.1 & 64 & 64.1 & 68 & 63.5 \\
\hline & Pied & 25.6 & 26 & 25.5 & 32 & 24.7 \\
\hline & Spotted & 10.3 & 10 & 10.3 & 0 & 11.8 \\
\hline \multirow[t]{10}{*}{ Coat colour type } & Red & 22.6 & 12 & 26.2 & 20 & 22.9 \\
\hline & White & 18.5 & 20 & 17.9 & 20 & 18.2 \\
\hline & Black & 11.3 & 14 & 10.3 & 8 & 11.8 \\
\hline & Brown & 2.6 & 4 & 2.8 & 0 & 2.9 \\
\hline & Grey & 7.7 & 6 & 7.6 & 4 & 8.2 \\
\hline & Roan & 4.1 & 4 & 4.1 & 12 & 2.9 \\
\hline & Whit dominant red, black or brown & 14.3 & 16 & 13.9 & 16 & 14.1 \\
\hline & Black dominant white or red & 8.2 & 12 & 6.9 & 12 & 7.7 \\
\hline & Red dominant white & 8.2 & 8 & 7.6 & 8 & 7.6 \\
\hline & Other colours & 2.5 & 4 & 2.8 & 0 & 3.6 \\
\hline
\end{tabular}



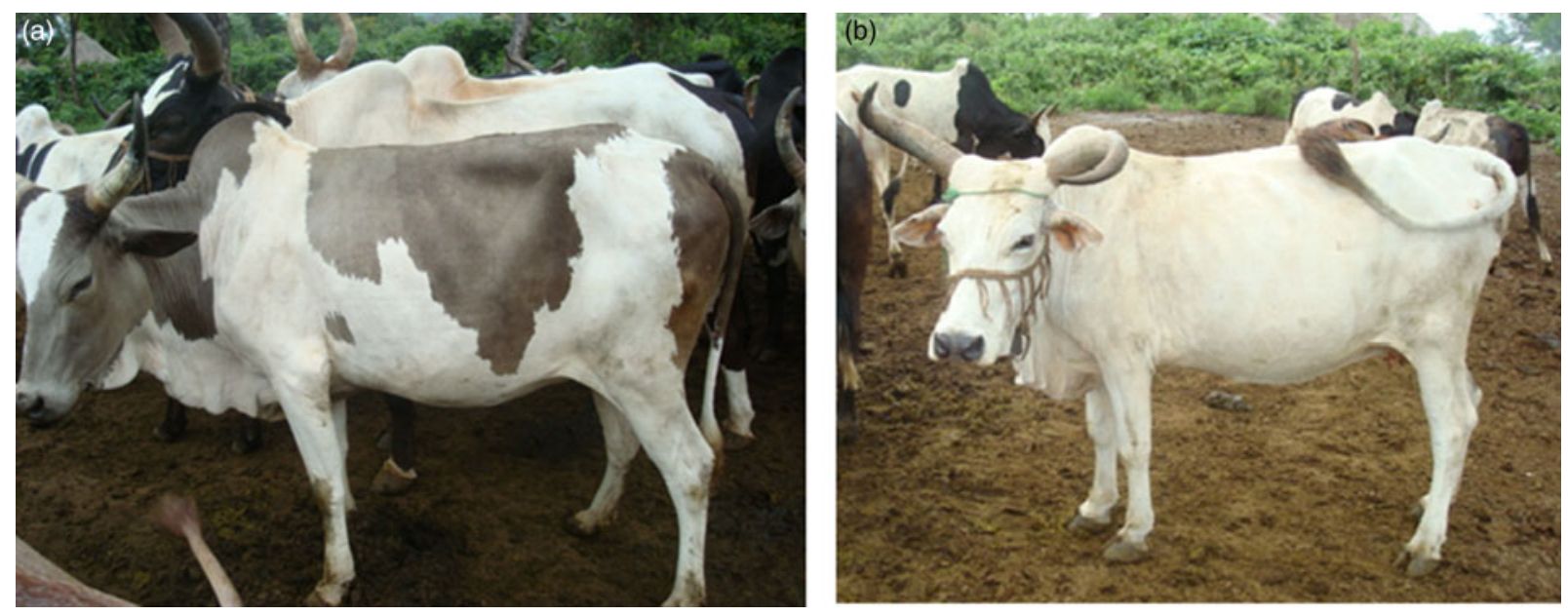

Figure 2. Coat colour type and colour pattern of a typical Mursi cows (a and b).
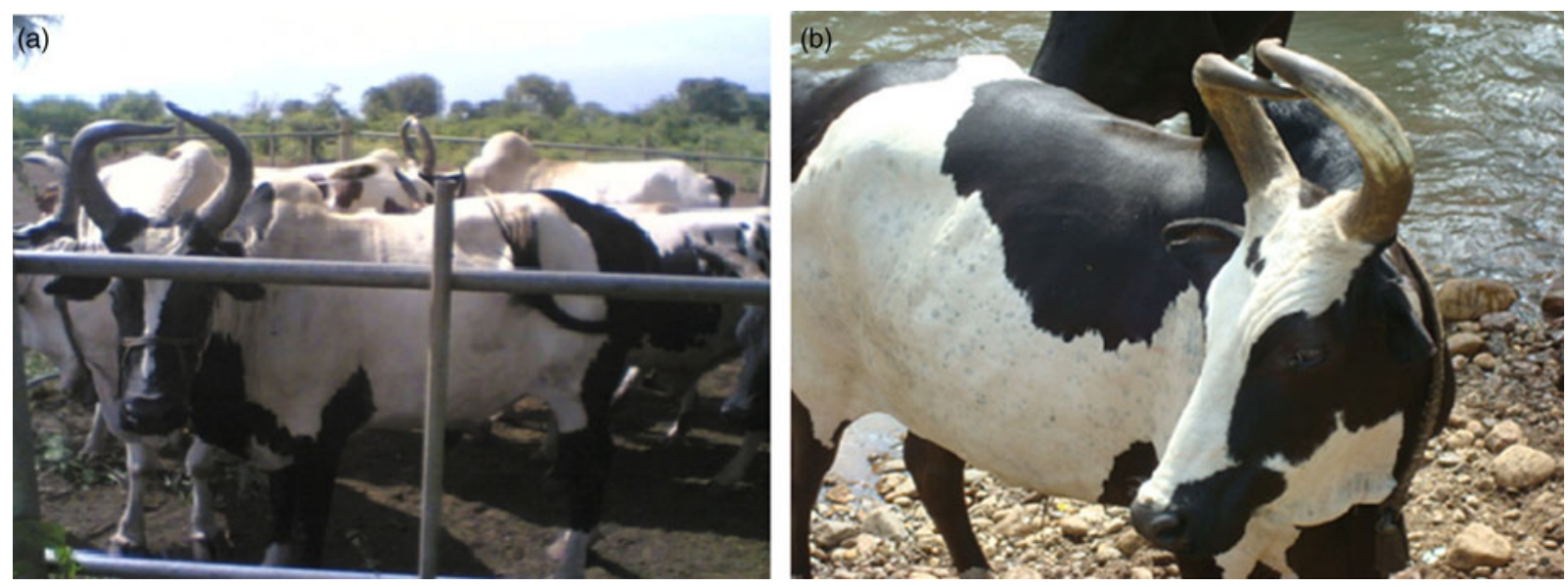

Figure 3. Typical Mursi bull with alternative (a) pied coat colour and (b) modified horn types.

Table 2. Body description (\%) of Mursi cattle in the Bodi and Mursi pastoral areas of South Omo zone, Southwest Ethiopia.

\begin{tabular}{|c|c|c|c|c|c|c|}
\hline \multicolumn{2}{|c|}{ Cattle body description } & \multirow[t]{2}{*}{ Overall } & \multicolumn{2}{|c|}{ Location } & \multicolumn{2}{|c|}{ Animal sex } \\
\hline & & & Bodi & Mursi & Male & Female \\
\hline \multirow[t]{2}{*}{ Horn nature } & Natural & 42.3 & 52 & 38.9 & 48 & 41.4 \\
\hline & Modified & 57.7 & 48 & 61.1 & 52 & 58.6 \\
\hline \multirow[t]{4}{*}{ Horn orientation } & Lateral & 5.7 & 8.0 & 4.9 & 12 & 4.8 \\
\hline & Forward & 22.8 & 20.0 & 23.8 & 24 & 22.6 \\
\hline & Straight & 69.4 & 70 & 69.2 & 64 & 70.2 \\
\hline & Drooping & 2.1 & 2 & 2.1 & 0 & 2.4 \\
\hline \multirow[t]{3}{*}{ Horn shape } & Scurs & 2.6 & 2 & 2.8 & 4 & 2.4 \\
\hline & Straight upward & 15.0 & 18 & 14.0 & 20 & 14.3 \\
\hline & Curved & 82.4 & 80 & 83.2 & 76 & 83.3 \\
\hline \multirow[t]{3}{*}{ Hump size } & Large & 13.5 & 12.2 & 13.9 & 48 & 8.3 \\
\hline & Medium & 22.3 & 12.3 & 25.7 & 44 & 19.1 \\
\hline & Small & 64.2 & 75.5 & 60.4 & 8 & 72.6 \\
\hline \multirow[t]{2}{*}{ Hump orientation } & Drooping & 2.6 & 8 & 0.7 & 12 & 1.2 \\
\hline & Erect & 97.4 & 92 & 99.3 & 88 & 98.8 \\
\hline \multirow[t]{3}{*}{ Udder size } & Small & 63.3 & 88.1 & 55.0 & - & 63.3 \\
\hline & Medium & 32.0 & 11.9 & 38.9 & - & 32.0 \\
\hline & Large & 4.7 & 0 & 6.1 & - & 4.7 \\
\hline \multirow[t]{3}{*}{ Temperament } & Docile & 75.5 & 64 & 79.5 & 69.2 & 76.5 \\
\hline & Moderately tractable & 19.4 & 32 & 15.0 & 23.1 & 18.8 \\
\hline & Aggressive /Wild & 5.1 & 4.0 & 5.5 & 7.7 & 4.7 \\
\hline
\end{tabular}


Table 3. Least square means and standard error of body measurements $(\mathrm{cm})$ of adult Mursi cattle in the Bodi and Mursi pastoral areas of South Omo zone, Southwest Ethiopia.

\begin{tabular}{|c|c|c|c|c|c|c|c|c|}
\hline \multirow[t]{2}{*}{ Measured traits } & \multirow[t]{2}{*}{ Over all } & \multirow[t]{2}{*}{ CV\% } & \multicolumn{3}{|c|}{ Location } & \multicolumn{3}{|c|}{ Sex } \\
\hline & & & Bodi & Mursi & SL & Female & Male & SL \\
\hline Body length & $122.1 \pm 0.9$ & 7.6 & $121.5 \pm 1.4$ & $122.7 \pm 1.0$ & ns & $114.9 \pm 0.8$ & $129.3 \pm 1.7$ & $* * *$ \\
\hline Chest girth & $144.5 \pm 0.9$ & 6.02 & $142.1 \pm 1.3$ & $146.8 \pm 0.9$ & $* * *$ & $134.3 \pm 0.7$ & $154.6 \pm 1.6$ & $* * *$ \\
\hline Height at wither & $113.0 \pm 1.1$ & 9.65 & $112.6 \pm 1.6$ & $113.3 \pm 1.2$ & ns & $104.6 \pm 0.9$ & $121.3 \pm 1.9$ & $* * *$ \\
\hline Rump width & $36.9 \pm 0.3$ & 8.4 & $37.8 \pm 0.5$ & $36.0 \pm 0.3$ & $* * *$ & $35.0 \pm 0.3$ & $38.8 \pm 0.6$ & $* * *$ \\
\hline Rump length & $20.4 \pm 0.3$ & 12.28 & $20.2 \pm 0.4$ & $20.7 \pm 0.3$ & ns & $18.4 \pm 0.2$ & $22.4 \pm 0.5$ & $* * *$ \\
\hline Tail length & $75.0 \pm 0.6$ & 8.04 & $73.4 \pm 0.9$ & $76.5 \pm 0.7$ & $* * *$ & $72.1 \pm 0.5$ & $77.9 \pm 1.1$ & $* * *$ \\
\hline Canon bone length & $19.6 \pm 0.2$ & 8.91 & $19.6 \pm 0.3$ & $19.6 \pm 0.2$ & ns & $18.9 \pm 0.2$ & $20.3 \pm 0.3$ & $* * *$ \\
\hline Canon bone circum. & $15.1 \pm 0.1$ & 9.16 & $15.0 \pm 0.2$ & $15.2 \pm 0.2$ & ns & $13.5 \pm 0.1$ & $16.7 \pm 0.35$ & $* * *$ \\
\hline Ear length & $18.6 \pm 0.3$ & 13.19 & $18.9 \pm 0.4$ & $18.3 \pm 0.3$ & ns & $18.3 \pm 0.2$ & $18.9 \pm 0.5$ & $\mathrm{~ns}$ \\
\hline Horn length & $30.8 \pm 1.1$ & 31.71 & $28.0 \pm 1.5$ & $33.5 \pm 1.1$ & $* * *$ & $27.0 \pm 0.8$ & $34.5 \pm 1.9$ & $* * *$ \\
\hline Face length & $39.3 \pm 0.3$ & 5.86 & $38.9 \pm 0.4$ & $39.6 \pm 0.3$ & ns & $37.4 \pm 0.2$ & $41.2 \pm 0.5$ & $* * *$ \\
\hline Dewlap width & $17.1 \pm 0.3$ & 19.83 & $17.0 \pm 0.5$ & $17.2 \pm 0.4$ & ns & $14.7 \pm 0.3$ & $19.5 \pm 0.6$ & $* * *$ \\
\hline Tail length & $75.0 \pm 0.6$ & 8.04 & $73.4 \pm 0.9$ & $76.5 \pm 0.7$ & $* * *$ & $72.1 \pm 0.5$ & $77.9 \pm 1.1$ & $* * *$ \\
\hline Teat length & $5.2 \pm 0.3$ & 25.3 & $5.6 \pm 0.6$ & $4.9 \pm 0.4$ & $* *$ & - & - & - \\
\hline
\end{tabular}

$\mathrm{SL}=$ significance level; $\mathrm{ns}=$ non-significant; $* *$ significant at $P<0.01 ; * * *$ significant at $P<0.001$.

and shape (0.29) may not be genetic but rather it might arise from horn modification made by individual cattle owners in the two communities (Table 2). The high coat colour variability observed in the population implies the existence of heterogeneity within the breed. This multiple coat colour and colour pattern variations come from preferential selection of the pastoral communities toward animals with variable coat colour pattern (Terefe et al., 2012) and uncontrolled mating.

\section{Quantitative body measurement}

The overall least-square means and standard error of body length, chest girth and height at withers were $122.1 \pm 0.9$, $144.5 \pm 0.9$ and $113.0 \pm 1.1 \mathrm{~cm}$, respectively (Table 3$)$. The measurements were significantly different $(P<0.001)$ between the male and female populations. No significant differences in body length and height at wither were observed between the cattle from the two locations. However, there were significant differences $(P<0.001)$ in chest girth, rump width, tail and horn length observed in Bodi and Mursi areas. Canon bone length and cannon bone circumference were $19.6 \pm 0.2$ and $15.1 \pm 0.1 \mathrm{~cm}$, respectively. Similarly, ear, horn, face, dewlap width and tail length measurements were $18.6 \pm 0.3,30.8 \pm 1.1$, $39.3 \pm 0.3, \quad 17.1 \pm 0.3$ and $75.0 \pm 0.6 \mathrm{~cm}$, respectively. The teat length of cows was $5.2 \pm 0.3 \mathrm{~cm}$ and longer $(P<0.01)$ cows in the Bodi $(5.6 \pm 0.6 \mathrm{~cm})$ than in the Mursi $(4.9 \pm 0.4 \mathrm{~cm})$ areas. The significant differences of some measured body morphological traits of cattle between the two locations might be due to within breed variability, which has been seen in most cattle breeds in Ethiopia using molecular studies (Fedlu et al., 2007). As a comparison with other cattle breed characterization results, the body measurements of Mursi cattle breed were superior to those of Kereyu cattle (Garoma, 2006) and Abigar (Nuer) cattle breeds (Minuye, 2009) under pastoral management system in Ethiopia, but its body frame is comparable with the Boran (Rege, 1999) and Ogaden cattle breeds (Mekuriaw, Ayalew and Hegde, 2009). Similarly, this breed was found to be superior to the taurine Sheko cattle breed, which survive and produce in trypanosome prevalent area (Ayalew, 2001).

\section{Performance characteristics of Mursi cattle}

\section{Reproductive performance}

The mean age at first breeding of male and female cattle were reported to be 3.6 and 3.4 years, respectively (Table 4). The average age at first calving (AFC) of the female Mursi cow was 4.6 years and it was significantly $(P<0.001)$ lower in the Bodi (4.3 years) than in the Mursi (4.9 years) herds. The calving interval (CI) of Mursi cow was found to be 14.5 months and did not differ in the two pastoral communities. However, no notable cattle husbandry practices were observed in the Bodi pastoral communities that led heifers to have a lower AFC (Terefe et al., 2012).

AFC and CI of Mursi cattle breed is similar to that reported by Tesfaye (2008) on the same breed. As a result, AFC of Mursi cattle in this study was similar to Kereyu cattle (Garoma, 2006) and Borana (Rege, 1999) cattle breeds under pastoral management. However, the CI was lower than in Ogaden cattle managed on station farm (Mekuriaw, Ayalew and Hegde, 2009), and Abigar cattle under pastoral management (Minuye, 2009). The lower $\mathrm{CI}$ in the Mursi cattle might be due to breed difference or uncontrolled breeding practice (Terefe et al., 2012). Similar to the Sheko cattle breed, which was reported as a trypanosome tolerant breed in Ethiopia (Lemecha et al., 2006), the Mursi cattle inhabit a trypanosome epidemic area, and the two breeds have similar reproductive performances such as AFC and CI (Taye, Ayalew and Hegde, 2007). The lower CI produces more calves per cow, which increases herd size that grants the production 
Table 4. Mean and standard deviation of reproductive performance of Mursi cattle in the Bodi and Mursi pastoral areas of South Omo zone, Southwest Ethiopia.

\begin{tabular}{|c|c|c|c|c|c|}
\hline \multirow[t]{2}{*}{ Reproductive traits } & \multicolumn{3}{|c|}{ Location } & \multirow[t]{2}{*}{$t$-value } & \multirow[t]{2}{*}{$P$-value* } \\
\hline & Bodi & Mursi & Overall & & \\
\hline Age at first service (year) & $3.4(0.7)$ & $3.6(0.6)$ & $3.4(0.7)$ & 1.59 & 0.115 \\
\hline Age at first calving (year) & $4.3(0.6)$ & $4.9(0.8)$ & $4.6(0.8)$ & 4.00 & 0.0001 \\
\hline Calving interval (month) & $14.8(5.3)$ & $14.2(4.0)$ & $14.5(4.5)$ & 0.55 & 0.582 \\
\hline Female reproductive life (year) & $13.5(3.2)$ & $14.6(2.9)$ & $14.2(3.1)$ & 1.697 & 0.093 \\
\hline Total calves born per cow lifetime & $10.6(2.7)$ & $11.4(1.7)$ & $11.0(2.2)$ & 1.71 & 0.091 \\
\hline Age at first mating of male (year) & $3.4(0.7)$ & $3.7(0.6)$ & $3.6(0.7)$ & 1.89 & 0.062 \\
\hline Male reproductive life (year) & $14.2(4.3)$ & $14.1(3.5)$ & $14.1(3.8)$ & 0.053 & 0.958 \\
\hline
\end{tabular}

*Significant at $P<0.05$.

of more milk from a larger number of cows in pastoral communities.

The mean reproductive lifetime of Mursi cow was reported to be 14.2 years. Within this reproductive lifetime, the mean number of calves born per cow was estimated to 11 calves (Table 4). The mean reproductive lifetime of Mursi cow is the same as the turine Sheko cattle breed (Taye, Ayalew and Hegde, 2007); however, the number of calves born in a lifetime of the Sheko cow is eight calves and is lower than the Mursi cow. The large number of calves per cow in Mursi cattle might be due to breed and management differences, with Mursi cattle being managed in open grazing compared with the restricted feeding management of Sheko cattle (Taye, Ayalew and Hegde, 2007). This uncontrolled breeding results all season reproduction of cattle as compared with the controlled breeding system (Mekonnen et al., 2012), which results in a large number of calves produced in a herd that can raise household herd size for sustainable milk production (Terefe et al., 2012).

\section{Milk production performance}

Cow milking frequency in the two pastoral communities was reported two times as twice a day, in the morning and evening after grazing. The interviewees estimated the amount of milk produced per cow per day in their herd by recalling the apparent milk yield in spite of cows' lactation stage and andty. The daily milk yield reported here is the amount excluding suckled by the calf. As a result, the daily milk production of Mursi cow does not exceed two "bakacha", local wooden milking container measuring on average an equivalent of 1.5 litres. The mean daily milk produced per cow for human purpose was estimated to be 2.1 litres and the amount produced in the two pastoral communities did not differ $(P>0.05)$. The Mursi cow produce a higher quantity of milk compared with Kereyou (Garoma, 2006), and Abigar (Minuye, 2009) cattle, which are adapted in trypanosome free area of the country and are managed under pastoral management system. However, the milk yield was similar to that of Sheko cattle breed (2.3 litres) which is adapted to trypanosome prevalent area of Southwest Ethiopia (Taye, Ayalew and Hegde, 2007). Similarly, the average lactation length of Mursi cow was estimated to be 7.8 months and did not significantly vary in the two locations. From the mean daily milk yield and lactation length, the lactation yield of Mursi cow was estimated to be 453.4 litres (Table 5).

\section{Cattle management practices}

Feed and feeding management

Natural pasture is the most common source for cattle grazing in the rainy season of the two locations. Beside to natural pasture, tree leaves and shrubs are used as cattle feed in rainy and dry periods (Table 6). In the two locations, 92.1 percent of the respondents said that the cattle feeding system is free grazing on communal grazing land. This system is a common feeding practice of cattle and other livestock in pastoral production system in the country. Some pastoral communities in the Mursi areas practice both free grazing and tethering, so that cattle that could

Table 5. Mean and standard deviation of milk production performance of Mursi cattle $(N=102)$ in the Bodi and Mursi pastoral areas of South Omo zone, Southwest Ethiopia

\begin{tabular}{lrrrrr}
\hline Milk production traits & & Locations & \multirow{2}{*}{$\boldsymbol{P}$-value } \\
\cline { 2 - 4 } & \multicolumn{1}{c}{ Bodi } & Mursi & Overall \\
\hline Lactation length (months) & $7.9(2.4)$ & $7.7(2.5)$ & $7.8(2.4)$ & 0.452 \\
Daily milk yield (litre) & $2.1(0.7)$ & $2.2(0.4)$ & $2.1(0.6)$ & 0.499 \\
Lactation milk yield (litre) & $455.7(1.6)$ & $451(1.4)$ & $453.4(1.5)$ & 0.652 \\
\hline
\end{tabular}

*Significant at $P<0.05$. 
Table 6. Response (\%) on feed resource and feeding management in the Bodi and Mursi pastoral communities in the Bodi and Mursi pastoral areas of South Omo zone, Southwest Ethiopia.

\begin{tabular}{lllll}
\hline \multirow{2}{*}{ Feed resource and utilization } & \multicolumn{3}{c}{ Location } \\
\cline { 3 - 5 } & & Bodi & Mursi & Overall \\
\hline Feed source in rainy & Natural pasture & 100 & 98.5 & 100 \\
season & & & & \\
& Tree/shrub leaf & 67.5 & 88.1 & 79.4 \\
Feed source in dry & Natural pasture & 83.7 & 86.4 & 85.3 \\
$\quad$ season & Tree/shrub leaf & 86.0 & 79.6 & 82.4 \\
& Free grazing & 97.7 & 86.4 & 92.1 \\
Grazing methods & Free grazing and & 0 & 13.6 & 7.9 \\
& tethering & & & \\
Seasonal feed shortage & Yes & 90.7 & 88.1 & 89.2 \\
& No & 9.3 & 11.9 & 10.8 \\
\hline
\end{tabular}

not move long distances, such as calves are usually tethered on grazing areas near to the homestead.

The majority of the pastoral communities (89.2 percent) responded that there is frequent seasonal feed shortage in quality and quantity in the two locations. This marked seasonal variation of feed resources is due seasonal variation in rainfall distribution (Tolera and Abebe, 2007). The problem is aggravated by absence of feed conservation practices by the pastoral communities for the dry season and frequent droughts due to prolonged dry periods. The communities usually solve seasonal cattle feed shortages by trekking their cattle to the Omo River and grazing on the flood-recessed area. However, sufficient feed is available in the wet season and cattle graze close to human housing, whereas in dry season, animals travel long distances and sometimes the communities shift their location during an extended dry period to areas where grazing is available. They do not provide supplemental feeds for cattle of any production status and age groups that are able to graze on natural pasture. However, a few respondents reported that they provide cut grass to calves and sick cattle, which are unable to move long distances.

\section{Cattle health management}

Disease is one of the major constraints of animal farming. The diseases identified from local naming in this study were based on their clinical signs and symptoms. According to the respondents, trypanosomosis, blackleg, anthrax and skin diseases were the major challenges to cattle production in the two pastoral areas (Table 7). Ticks and mangemites were the observed external parasites and where a critical problem in the area. The communities report that Contagious Bovine Pleuropneumonia (CBPP) and Pasteurellosis were the main cattle diseases that cause significant losses through cattle death and reduction of production.

The communities use traditional medication to prevent and treat cattle diseases. Local herbs are used to treat sick animals. Moreover, they usually smoke the barns to protect
Table 7. Response (\%) on major cattle diseases in the Bodi and Mursi pastoral areas of South Omo zone, Southwest Ethiopia.

\begin{tabular}{lccc}
\hline Major cattle disease & \multicolumn{3}{c}{ Locations } \\
\cline { 2 - 4 } & Bodi & Mursi & Overall \\
\hline Trypanosomosis & 100 & 100 & 100 \\
Black leg & 93.0 & 86.4 & 89.2 \\
Anthrax & 74.7 & 84.4 & 81.4 \\
Contagious Bovine Pleuropneumonia & 39.5 & 22.0 & 29.4 \\
Pasteurellosis & 23.3 & 18.6 & 20.6 \\
Internal and external parasites & 46.5 & 79.7 & 65.7 \\
Skin disease & 51.2 & 88.1 & 72.6 \\
Mastitis & 14.0 & 16.9 & 15.7 \\
Poisonous plants & 7.0 & 5.1 & 5.9 \\
\hline
\end{tabular}

cattle from tsetse fly biting. The communities move their cattle away from tsetse fly infested areas when there is a high infestation during the wet season. Animals are watered at noon when tsetse flies become inactive and hide under vegetation to protect themselves from the intense heat (FAO, 1982).

\section{Major cattle production constraints}

The main cattle production constraints reported by the Bodi communities were disease and parasite (rank index of 0.27$)$, seasonal feed $(0.26)$ and water $(0.22)$ shortages (Figure 4). While the Mursi pastoralist ranked water shortage $(0.35)$ as their first priority problem and feed $(0.33)$ and animal disease (0.11) were second and third in their area. The Bodi communities settle along the Gura a river where water is available for livestock and human consumption, while the Mursi people live far from a water source and state this as the community's primary problem. Water and feed shortage due to erratic rainfall were the major challenges to cattle production in the two study locations, mainly in the Mursi area. The prolonged absence of rainfall in the area leads to drought that causes animal

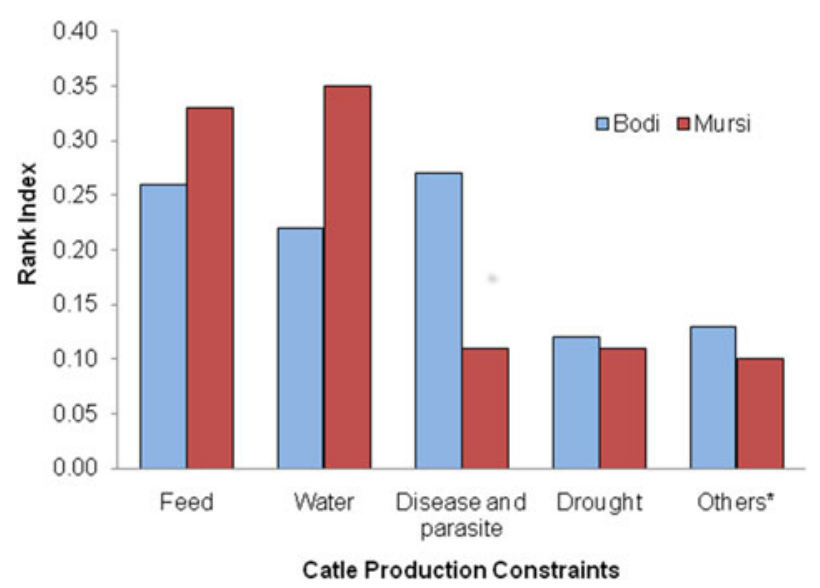

Figure 4. Rank indices of major cattle production constraints in Bodi and Mursi pastoral communities in South Omo Zone, Southwest Ethiopia. (*Other production constraints include veterinary services, wild predators, infrastructure such as Market and roads, theft and conflicts that result in cattle raiding.) 
disease outbreaks and results in high cattle mortality. To cope with these problems, the communities move their herd to areas where pasture and water are available and usually cause conflict with neighbouring ethnic groups due to the sharing of resources and can result in theft and raiding of cattle.

Inadequate or complete absence of veterinary services in the area, absence of livestock markets and roads were identified as the major production constraints in the Bodi and Mursi pastoral communities. Absence of market in the areas limited the availability of production inputs such as veterinary supplies, sale of animals and animal products, which influence herd growth, productivity, and general livelihood of the pastoral communities. Hana and Jinka, the Salamago Wereda and South Omo zone administrative towns, respectively, are the only two small marketing places where the Bodi and Mursi communities have to travel long distances for marketing. In these markets, the communities sell their animals and purchase food grains especially in the long dry season. During this period, the communities' consume mainly a grain-based diet since milk production is low and not sufficient for household consumption. Therefore, the communities have to travel a long distance to sell their cattle in distant markets and even in some worse drought seasons, they exchange live animals for food grains (Terefe et al., 2012).

Disease and parasite prevalence were among the listed main constraint that hindered cattle production in the Bodi and Mursi communities. This high disease and parasitic problem in the area might arise from the presence of different wild animals in the area that share common national park ecosystem with the livestock (Bengis, 2003). Besides being a disease and parasite reservoir, the wild animals are potential predators of livestock and are challenges to cattle production in the areas. This is because the communities graze their cattle in the national parks in dry season when grazing pasture is scarce. This situation is common for most pastoral areas that inhabit and share national park boundaries (Gegner, 2002) and these cause significant losses in cattle numbers.

\section{Conclusion}

The Mursi cattle breed shows morphological variability. This variability indicates absence of directional selection towards particular objective traits. However, the breed shows peculiar morphological characteristics that enable the separation of Mursi cattle from other breeds and ecotypes. On the other hand, the morphological variability may have contributed to its survival and production in the hot and humid environment where trypanosome is highly prevalent.

The long and large body frame of Mursi cattle compared to some breeds in the country means it could be a genetic resource to use in improvement programs. It provides an option to maximize beef production to satisfy the everincreasing demand. The breed produces a higher quantity of milk compared with other indigenous cattle breeds that are managed under pastoral management system. The breed can also be used as a potential genetic resource to improve milk production through implementing appropriate breeding strategy in the pastoral production system. With this genetic potential, introducing the breed to a smallholder mixed production system, increases cattle genetic resource for alternate breed improvement in the country.

Even though the breed survives and produces through tolerating the existing hostile environment and trypanosomosis challenge, cattle production in the area is constrained by prevalent disease, seasonal feed and water shortages, and frequent drought. Absence of frequent vaccination and treatment of cattle in such hostile environment make the area potential to harbouring epidemic diseases and parasites that cause loss of cattle number. Therefore, alleviating these constraints should increase the productivity of Mursi cattle in their natural environment.

\section{Acknowledgements}

The authors would like to acknowledge ILRI for allocating the required budget and providing facilities for this study. We also acknowledge the South Omo zone and Salamago Wereda Administration and Agriculture office and Kebele agricultural development agents. Finally, we would like to forward our gratitude to the pastoral communities' leaders for smoothing the progress of the study.

\section{References}

Albero, M. \& Solomon, H.-M. 1982a. The indigenous cattle of Ethiopia, Part I. World Anim. Rev., 41: 2-10.

Albero, M. \& Solomon, H.-M. 1982b. The indigenous cattle of Ethiopia, Part II. World Anim. Rev., 41: 27-42.

Ayalew, W. 2001. Revised filed Report on survey of a sample of the Sheko cattle maintained at the former Trolley Military Training Center (available at http://dagris.ilri.cgiar.org)

Ayalew, W. \& Rowlands (eds). 2004. Design, execution and analysis of the livestock breed survey in Oromiya Regional State, Ethiopia. Addis Ababa, Ethiopia, OADB (Oromiya Agricultural Development Bureau), and ILRI (International Livestock Research Institute), Nairobi, Kenya. 260 p.

Ayalew, W., Ephrem, G., Markos, T., Yetnayet, M. \& Rege, J.E.O. 2004. Current state of knowledge on characterization of farm animal genetic resources in Ethiopia. In Proceedings of the 11th Annual conference of the Ethiopian Society of Animal Production (ESAP) held in Addis Ababa, Ethiopia, 28-30 August, 2003. pp. 1-21.

Bengis, R.G. 2003. Transfrontier Conservation Area Initiatives in, Sub-Saharan Africa: Some Animal Health Challenges. In Proceedings of the Southern and East African Experts Panel on Designing Successful Conservation and Development Interventions at the Wildlife/Livestock Interface: Implications for Wildlife, 
Livestock and Human Health, AHEAD (Animal Health for the Environment and Development) Forum, IUCN (The World Conservation Union) 5th World Parks Congress, 14-15 September, Durban, South Africa.

DAGRIS. 2007. Domestic Animal Genetic Resources Information System (DAGRIS). (eds. S. Kemp, Y. Mamo, B. Asrat and T. Dessie) International Livestock Research Institute, Addis Ababa, Ethiopia (available at http://dagris.ilri.cgiar.org).

FAO, 1982. Training manual for tsetse control personnel. In N. Pollock (ed.) Tsetse biology, systematic and distribution techniques, Vol. 1. Rome, Food and Agriculture Organization of the United Nations (FAO), p274.

FAO. 2007. The State of the World's Animal Genetic Resources for Food and Agriculture, edited by Barbara Rischkowsky \& Dafydd Pilling. Rome (available at http://www.fao.org/docrep/010/a1250e/ a1250e00.htm)

FAO. 2012. Phenotypic characterization of animal genetic resources. FAO Animal Production and Health Guidelines No. 11. Rome (available at http://www.fao.org/docrep/015/i2686e/i26).

Fedlu, H., Bekele, E., Ayalew, W. \& Dessie, T. 2007. Genetic variability of five Indigenous Ethiopian Cattle Breeds using RAPD markers. Afr. J. Biotechnol., 6(19): 2274-2279.

Garoma, S. 2006. In-Situ characterization of Kereyou Cattle Type in Fentalle District of Oromia Region, Ethiopia. Presented to the School of Graduate Studies of Haramaya University. 122 p (MSc thesis).

Gegner, L.E. 2002. Predator Control for Sustainable \& Organic Livestock Production. Livestock Technical Note. 16 p (available at http://www.attra.org/attra-pub/PDF/predator.pdf).

Kader, G.D. \& Perry, M. 2007. Variability for categorical variables J. Stat. Educ., 15(2) (available at http://www.amstat.org/publications/ jse/v15n2/kader.html)

Lemecha, H., Woudyalew, M., Hussein, I., Rege, J.E.O., Tekle, T., Abdicho, S. \& Ayalew, W. 2006. Response of four indigenous cattle breeds to natural tsetse and trypanosomosis challenge in the Ghibe valley of Ethiopia. Vet. Parasitol., 141(1-2): 165-176.

Makokha, S.N., Karugiab, J., Staalc, S. \& Kosura, O. 2006. Valuation of cow attributes by conjoint analysis: a case study in Western Kenya. In Contributed paper prepared for presentation at the International Association of Agricultural Economists Conference, August 12-18, 2006, Gold Coast, Australia (available at http://ageconsearch.umn. edu/bitstream/25752/1/cp060765.pdf) (accessed 22 July 2010).

Mekonnen, A., Haile, A., Dessie, T. \& Mekasha, Y. 2012. On farm characterization of Horro cattle breed production systems in western
Oromia, Ethiopia. Livestock Research for Rural Development Volume 24, Article \#100 (available at http://www.lrrd.org/lrrd24/6/ meko24100.htm)

Mekuriaw, G., Ayalew, W. \& Hegde, P.B. 2009. Growth and reproductive performance of Ogaden cattle at Haramaya University, Ethiopia. Eth. J. Anim. Prod., 9(1): 13-38.

Minuye, N. 2009. Characterization of Abigar (Nuer) Cattle Breed at Its Production Environment in Gambella Regional State, Ethiopia. Submited to the School of Graduate Studies Hawassa University. 159 p. (MSC thesis)

Olson, T.A., Lucena, C., Chase, C.C. \& Hammond, A.C. 2003 Evidence of a major gene influencing hair length and heat tolerance in Bos taurus cattle. J. Anim. Science, 81: 80-90.

Rege, J.E.O. 1999. The state of African cattle genetic resources I. Classification framework and identification of threatened and extinct breeds. Anim. Genet. Resour. Inf. Bull., 25: 1-25.

Rege, J.E.O. \& Tawah, C.L. 1999. The state of African cattle genetic resources II. Geographical distribution, characteristics and uses of present-day breeds and strains. Anim. Genet. Resour. Inf. Bull., 26: $1-25$.

Taye, T. Ayalew, W. \& Hegde, B.P. 2007. On-farm characterization of Sheko Breed of cattle in Southwestern Ethiopia. Eth. J. Anim. Prod., 7(1): 89-105.

Terefe, E., Dessie, T., Haile, A., Mulatu, W. \& Mwai, O. 2012. Husbandry and breeding practices of cattle in Mursi and Bodi pastoral communities in Southwest Ethiopia. Afr. J. Agric. Res., 7(45): 59865994.

Terefe, E., Haile, A., Mulatu, W., Dessie, T. \& Mwai, O. 2015 Phenotypic characteristics and trypanosome prevalence of Mursi cattle breed in the Bodi and Mursi districts of South Omo Zone, Southwest Ethiopia. Trop. Anim. Health Prod., 47(3): 485-493.

Tesfaye, M. 2008. Range-Livestock Management Practices and Condition Assessment of the Rangelands in Mursi-Bodi (Salamago) District of the SNNPR, Ethiopia. Awassa College of Agriculture, School of Graduate Studies, Hawassa University. pp 136. (MSc thesis)

Tolera, A. \& Abebe, A. 2007. Livestock production in pastoral and agropastoral production systems of southern Ethiopia. Livest. Res. Rural Dev., 19(177) (available at http://www.lrrd.org/lrrd19/12/tole19177. $\mathrm{htm})$.

Zerabruk, M., Li, M.H., Kantanen, J., Olsaker, I., Ibeagha-Awemu, E.M., Erhardt, G. \& Vangen, O. 2012. Genetic diversity and admixture of indigenous cattle from North Ethiopia: implications of historical introgressions in the gateway region to Africa. Anim. Genet., 43 (3): $257-266$ 